\title{
Correction to: "Dealing with the changeable and blurry edges of living things: a modified version of property-cluster kinds"
}

\author{
María J. Ferreira Ruiz ${ }^{1,2} \cdot$ Jon Umerez ${ }^{3}$ \\ Published online: 23 August 2018 \\ (C) The Author(s) 2018
}

\section{Correction to: Euro Jnl Phil Sci \\ https://doi.org/10.1007/s13194-018-0210-z}

The article "Dealing with the changeable and blurry edges of living things: a modified version of property-cluster kinds", written by María J. Ferreira Ruiz and Jon Umerez, was originally published electronically on the publisher's internet portal (currently SpringerLink) on 29 June 2018 without open access.

With the author(s)' decision to opt for Open Choice the copyright of the article changed on 13 August 2018 to (C) The Author(s) 2018 and the article is forthwith distributed under the terms of the Creative Commons Attribution 4.0 International License (http://creativecommons.org/licenses/by/4.0/), which permits use, duplication, adaptation, distribution and reproduction in any medium or format, as long as you give appropriate credit to the original author(s) and the source, provide a link to the Creative Commons license and indicate if changes were made.

The original article has been corrected.

The online version of the original article can be found at https://doi.org/10.1007/s13194-018-0210-z

María J. Ferreira Ruiz

mariaferreiraruiz@gmail.com

Jon Umerez

jon.umerez@ehu.eus

1 Department of Philosophy, University of Geneva, 5, Rue de-Candolle, 1211 Genève 4, Switzerland

2 Department of Philosophy, University of Buenos Aires - CONICET, Buenos Aires, Argentina

3 Department of Logic and Philosophy of Science, University of the Basque Country, Avenida Tolosa, 70, 20018, SAN SEBASTIAN, Gipuzkoa, Basque Country, Spain 
Open Access This article is distributed under the terms of the Creative Commons Attribution 4.0 International License (http://creativecommons.org/licenses/by/4.0/), which permits unrestricted use, distribution, and reproduction in any medium, provided you give appropriate credit to the original author(s) and the source, provide a link to the Creative Commons license, and indicate if changes were made. 